\title{
Membrane manipulations by the ESCRT machinery [version 1;
}

\section{peer review: 4 approved]}

\section{Greg Odorizzi}

Molecular, Cellular, and Developmental Biology, University of Colorado, Boulder, CO, USA

V1 First published: 07 Aug 2015, 4(F1000 Faculty Rev):516
https://doi.org/10.12688/f1000research.6319.1

Latest published: 07 Aug 2015, 4(F1000 Faculty Rev):516

https://doi.org/10.12688/f1000research.6319.1

\section{Abstract}

The endosomal sorting complexes required for transport (ESCRTs) collectively comprise a machinery that was first known for its function in the degradation of transmembrane proteins in the endocytic pathway of eukaryotic cells. Since their discovery, however, ESCRTs have been recognized as playing important roles at the plasma membrane, which appears to be the original site of function for the ESCRT machinery. This article reviews some of the major research findings that have shaped our current understanding of how the ESCRT machinery controls membrane dynamics and considers new roles for the ESCRT machinery that might be driven by these mechanisms.

\section{Keywords}

ESCRT, ESCRT machinery, endosomal sorting complexes required for transport, membrane dynamics, intralumenal vesicle budding pathway, retrovirus budding, cytokinesis

\author{
Open Peer Review \\ Approval Status $\checkmark \checkmark \checkmark$ \\ $\begin{array}{llll}1 & 2 & 3 & 4\end{array}$ \\ version 1 \\ 07 Aug 2015 \\ 1. David Teis, Innsbruck Medical University, \\ Innsbruck, Austria \\ 2. Winfried Weissenhorn, University Joseph \\ Fourier, Grenoble, France \\ 3. Jon Audhya, University of Wisconsin- \\ Madison, Madison, USA

\section{Phyllis Hanson, Washington University \\ School of Medicine, St. Louis, USA} \\ Any comments on the article can be found at the \\ end of the article.
}

Corresponding author: Greg Odorizzi (odorizzi@colorado.edu)

Competing interests: The author declares that he has no competing interests.

Grant information: The author(s) declared that no grants were involved in supporting this work.

Copyright: $\odot 2015$ Odorizzi G. This is an open access article distributed under the terms of the Creative Commons Attribution License, which permits unrestricted use, distribution, and reproduction in any medium, provided the original work is properly cited.

How to cite this article: Odorizzi G. Membrane manipulations by the ESCRT machinery [version 1; peer review: 4 approved] F1000Research 2015, 4(F1000 Faculty Rev):516 https://doi.org/10.12688/f1000research.6319.1

First published: 07 Aug 2015, 4(F1000 Faculty Rev):516 https://doi.org/10.12688/f1000research.6319.1 
Genes encoding the proteins that came to be known collectively as the endosomal sorting complexes required for transport (ESCRT) machinery were discovered in the yeast Saccharomyces cerevisiae ${ }^{1}$. Genetic screens revealed these genes to be required for the sorting of transmembrane proteins into intralumenal vesicles (ILVs) that bud into the endosome lumen ${ }^{2,3}$. Biochemical studies assigned the different yeast gene products into distinct protein complexes that were dubbed ESCRTs ${ }^{4-7}$. Although they were defined in yeast, almost every protein subunit that belongs to an ESCRT complex can also be identified in every other eukaryotic genome, although ESCRT-0 appears restricted to metazoans and fungi ${ }^{8}$, and some orthologs are also found in archaeal species ${ }^{9,10}$. Such comprehensive distribution implies that at least some of the functions executed by the ESCRT machinery are highly conserved.

\section{ESCRTs in the intralumenal vesicle budding pathway}

A key insight at the time of its discovery was that the ESCRT-I complex binds ubiquitin ${ }^{4}$. ESCRT-0 was subsequently found to have the same ubiquitin-binding property ${ }^{7}$, as was ESCRT-II ${ }^{11}$. Shortly before the ESCRTs were described as ubiquitin-binding protein complexes, studies revealed that many transmembrane proteins at the plasma membrane are ubiquitinated on their cytosolic domains and that this modification was essential for their degradation at lysosomes ${ }^{12}$. Together, these observations established that one of the functions of the ESCRT machinery is to target ubiquitinated transmembrane proteins for lysosomal degradation by sorting them at endosomes into ILVs, which then are exposed to degradative hydrolytic enzymes when late endosomes fuse with lysosomes (Figure 1A).

Lagging behind the advances in understanding how ESCRTs recognize ubiquitinated ILV cargoes was insight into how the ILVs are actually created. This impasse was breached 10 years later with the discovery that purified subunits of the yeast ESCRT-III complex, when added to synthetic liposomes, can catalyze the membrane scission reaction required for the detachment of ILVs from the limiting membrane ${ }^{13}$. This observation explained why dominantnegative alleles that affect ESCRT-III function in vivo had been seen in earlier studies to disrupt the budding of retroviruses, a process that is topologically similar to ILV budding and also dependent upon the ESCRT machinery (see below). The same experimental system showed that purified yeast ESCRT-I and ESCRT-II complexes can cooperate with one another to induce the membrane invagination step that initiates ILV budding ${ }^{14}$. Thus, a broad outline of the division of functions executed by the ESCRT machinery at endosomes was proposed: ESCRT-0, ESCRT-I, and ESCRT-II concentrate ubiquitinated transmembrane proteins at membrane microdomains, where ESCRT-I and ESCRT-II produce incipient buds that are pinched off by the membrane scission activity of ESCRT-III.

Despite the assignment of activities performed by certain ESCRTs that was suggested in vitro ${ }^{13,14}$, many of the details about their operations remain fuzzy. Perhaps the wooliest thinking concerns ESCRT-III structure-function. What makes it troublesome to study

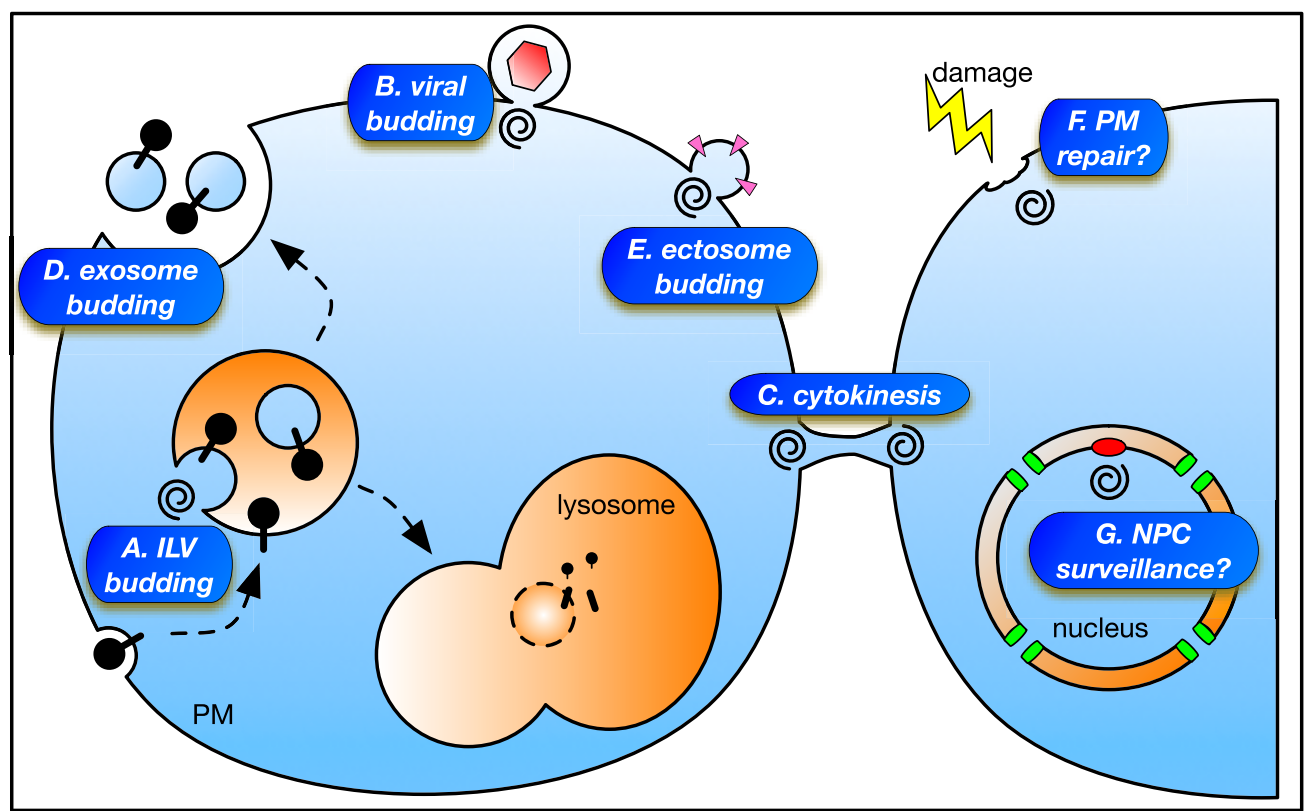

Figure 1. Broad overview of endosomal sorting complex required for transport (ESCRT) activities in membrane dynamics. ESCRTS are generally represented by a spiral, which reflects the conformation adopted by ESCRT-III. (A) In the intralumenal vesicle (ILV) budding pathway, ESCRTs sort transmembrane proteins at endosomes into ILVs that are degraded when endosomes fuse with lysosomes. (B) In the viral budding pathway, ESCRTs are required at the plasma membrane (PM) for the release of infectious viral particles. (C) In the abscission step of cytokinesis, ESCRTs are required at the PM for membrane scission that separates dividing cells. (D) In the exosome budding pathway, ILVs created by ESCRTs at endosomes are released into the extracellular environment when endosomes fuse with the PM. (E) In the ectosome budding pathway, extracellular vesicles are released directly from the PM. Recent studies implicate the ESCRT machinery functioning in the repair of PM damage $(\mathbf{F})$ and in the elimination of dysfunctional nuclear pore complex (NPC) intermediates (denoted in red) from the inner nuclear membrane $(\mathbf{G})$ 
is that ESCRT-III is not a stable protein complex. Instead, its subunits exist in two states that are in equilibrium with one another: subunits either are monomeric and soluble in the cytosol or associate with membranes, where they polymerize into the ESCRT-III complex ${ }^{6,15}$. All of the ESCRT-III subunits are homologous to one another and are predicted to have the same three-dimensional (3D) structure, yet structures have been determined for only some of the subunits (either in whole or in part), and these structures were solved either for an individual subunit or for two different subunits bound to one another ${ }^{16-19}$ but not for all of the subunits co-assembled together. Macromolecular structures that correspond to ESCRT-III on membranes in vivo have been visualized by electron microscopy $(\mathrm{EM})^{20,21}$, but no studies have unambiguously solved a structure of the complete ESCRT-III complex in relative isolation. Even the stoichiometry of its subunits has been defined only in relatively loose terms $^{22}$.

Murkier still is the mechanism by which ESCRT-III drives the membrane scission reaction. This topic has been reviewed often (e.g., 23) and can be boiled down to two working models. One proposes that the polymerization of ESCRT-III subunits mediates scission. This model draws its support from in vitro studies, including the original demonstration that purified ESCRT-III subunits assembled on synthetic membranes catalyze membrane scission; in this assay, the disassembly of ESCRT-III was necessary only for the replenishment of subunits so that they can participate in further rounds of complex assembly ${ }^{13}$. An assembly-driven model for scission is also supported by EM of purified ESCRT-III subunits that, when combined with one another, polymerize into tubules constricted at one end to form a dome shape ${ }^{17}$. This particular conformation led to the idea that the assembly of membrane-associated subunits at the neck of an ILV invagination would narrow the membrane to terminate in constriction and culminate in scission ${ }^{24}$, but whether a dome-shaped structure is formed by ESCRT-III in vivo is unknown.

The other model contends that membrane scission by ESCRT-III is coupled to disassembly of the complex by VPS4, a member of the broader family of AAA+ ATPases that are known for their roles in the disassembly of macromolecular complexes. This model is supported by studies conducted in intact cells showing that scission is stalled when VPS4 activity is inhibited ${ }^{20,25,26}$. Like other AAA+ ATPases, ATP-bound VPS4 assembles into a ring-shaped oligomer with a central pore. The amino terminus of VPS4 is oriented toward the pore of the oligomer, and this region has a domain that binds directly to a motif located in each ESCRT-III subunit ${ }^{9,27,28}$. Via this interaction, it is thought that VPS4 rips the ESCRT-III complex apart by extruding each individual subunit in succession through its pore when it hydrolyzes ATP. Conceivably, this action could shorten the ESCRT-III complex to gradually draw together the attached membrane in the neck of an ILV constriction, ultimately resulting in scission $^{29}$. An alternative scenario consistent with studies conducted in vivo is that the engagement of VPS4 with ESCRT-III substrates alters the conformation of the ESCRT-III polymer, potentially serving to catalyze the membrane scission reaction ${ }^{20,30,31}$.

Despite uncertainties surrounding the native structure of ESCRT-III in vivo and the mechanism by which it drives membrane scission, its function in this process is well supported by studies revealing that the role of ESCRT-III is not restricted to the ILV budding pathway. Indeed, the membrane scission activity of ESCRT-III appears to have essential roles in cellular processes that are unrelated to transmembrane protein degradation. These activities are considered below.

\section{ESCRT activity in retrovirus budding}

Very shortly after they were reported to function in the ILV budding pathway, ESCRT-I and VPS4 were discovered to have a role in the budding of human immunodeficiency virus-1 (HIV-1) from the plasma membrane of infected cells ${ }^{32}$. In addition to exposing ESCRTs as having non-endosomal functions, this landmark report opened the door for an explosion of studies revealing that a subset of ESCRTs are generally required for the budding of all retroviruses and for many non-retroviral classes of viruses (reviewed in 33). Exploitation of the ESCRT machinery is driven by virally encoded proteins that recruit one or more ESCRT subunits to the membrane microdomain where new viruses are being packaged, the goal being to nucleate a protein interaction network that mediates recruitment of ESCRT-III ${ }^{34}$. Viral budding critically depends upon ESCRT-III (and VPS4) to catalyze the membrane scission reaction necessary for the release of a virion from the host cell membrane (Figure 1B). Thus, like the ILV budding pathway, the retroviral budding pathway depends on ESCRT-III/VPS4 at the final step to sever the membrane.

The identities of ESCRTs, aside from ESCRT-III/VPS4, recruited by each retrovirus are idiosyncratic. For instance, HIV-1 recruits both ESCRT-I $^{32}$ and ALIX, the latter of which interacts with ESCRTIII $^{35}$, whereas the equine infectious anemia virus recruits only $\mathrm{ALIX}^{35}$. The reason for selective utilization of components outside of the core ESCRT-III/VPS4 machinery might be that viruses do not need all of the activities that are performed by ESCRT complexes 0 , I, and II in the ILV budding pathway ${ }^{33}$. For example, the structural proteins encoded by viruses can target themselves to the site of viral assembly and autonomously generate the membrane curvature needed to produce a virion. That different viruses recruit different ESCRTs to facilitate their exploitation of the membrane scission activity performed by ESCRT-III/VPS4 is a reflection of how evolution allows different solutions for the same problem.

Notably, studies of how viruses take advantage of ESCRTs have yielded fundamental advances in understanding mechanisms that are likely common to all pathways that use ESCRT-III/VPS4. For example, the HIV-1 budding pathway was found to be affected by truncation of ESCRT-III subunits, leading to structure-function analyses demonstrating that the carboxyl termini of several ESCRTIII subunits make intramolecular contacts with their amino-terminal core regions to maintain the proteins as inactive subunits that are incapable of assembling into the ESCRT-III complex ${ }^{16,36,37}$. More recently, 3D super-resolution microscopy and correlative EM outlined the nanoscale organization within the head of budding HIV-1 virions, suggesting that VPS4 functions at least in part to remodel subunits assembled into the ESCRT-III complex during the membrane constriction process that leads to scission ${ }^{38}$. A direct role for VPS4 in membrane scission during retrovirus budding was also supported by light microscopy studies that tracked HIV-1 recruitment of ESCRTs over time to the plasma membrane of live cells ${ }^{39,40}$. 
In addition to characterizing the mechanisms of viral exploitation of the ESCRT machinery, investigations of this process helped lead to the unexpected discovery that ESCRT-III/VPS4 has a role during cytokinesis in animal cells, as discussed in the next section.

\section{ESCRT activities during cytokinesis}

In metazoans, dividing daughter cells are connected by a relatively thin $(200 \mathrm{~nm})$ membrane tubule known as the midbody. A process termed abscission severs the midbody connection, and this step appears to depend on the membrane scission activity of ESCRT-III/VPS4 (Figure 1C; reviewed in 41). This discovery originated from serendipitous observations in a number of disparate studies, not all of which were aimed at understanding ESCRT functions per se, and was bolstered by proteomic studies that identified several ESCRT-binding proteins implicated to function at the midbody. Focused analyses of ESCRTs in cytokinesis revealed that the TSG101 subunit of human ESCRT-I binds directly to CEP55, a microtubule bundling protein, and this interaction mediates ESCRT-I recruitment to the midbody ${ }^{42-44}$. TSG101 also binds ALIX, the ESCRT-III-associated protein mentioned above ${ }^{45,46}$. Colocalization of ALIX with TSG101 to the midbody was found to require CEP55, and, consistent with their function during cytokinesis, knocking down TSG101 or ALIX expression results in multi-nucleated cells, and this is a hallmark cytokinetic defect ${ }^{42-44}$.

The point of CEP55 mediating recruitment of TSG101/ALIX appears to be so that ALIX can mediate recruitment of CHMP4B, which is the predominant subunit comprising the ESCRT-III complex. As in the ILV and viral budding pathways, ESCRT-III assembly within the midbody neck is expected to constrict the membrane. Three-dimensional electron tomography of the midbody revealed 17-nm-thick spiral filaments adjacent to membrane constrictions ${ }^{21}$, analogous to spirals of CHMP4B at the plasma membrane that were observed by deep-etch $\mathrm{EM}^{20}$. However, immunolabeling confirmed that the spirals imaged in the latter study were comprised of CHMP4B, and these spirals measured only $5 \mathrm{~nm}$ in thickness ${ }^{20}$, which is close to the 9-nm-thick spirals of the purified yeast ortholog of CHMP4B that were seen in vitro by negative staining $\mathrm{EM}^{47}$ and the 4-nm-thick spirals of the Caenorhabditis elegans ortholog of CHMP4B observed in vitro by cryo $\mathrm{EM}^{31}$. The severe limitations of immunolabeling in electron tomography made it impossible to confirm that CHMP4B (or other ESCRT-III subunits) comprise the 17-nm spiral filaments in the midbody, although this identity seems likely, given that formation of these filaments was dependent upon expression of a different subunit of the ESCRT-III complex ${ }^{21}$. Given that several cytoskeletal elements also oligomerize into filaments within the midbody, something else might comprise the 17-nm spiral structures presumed to be ESCRT-III; alternatively, ESCRT-III might co-assemble with something else (or with itself in parallel polymers) to form the 17-nm filaments seen by tomography.

Notwithstanding the uncertainties described above, a role for ESCRT-III/VPS4 in membrane scission during cytokinesis is strongly supported by other lines of evidence. First and foremost is the discovery that orthologs of VPS4 and ESCRT-III subunits mediate cytokinesis during cell division in archaebacterial species ${ }^{10,48}$. Thus, the function of ESCRT-III/VPS4 most likely originated for this purpose. Additionally, time-lapse imaging by high-resolution light microscopy showed sequential recruitment of TSG101 and
CHMP4B to the intercellular membrane bridge of the midbody connecting daughter cells, followed by VPS4, whereupon cell separation occurs ${ }^{49}$. Curiously, the kinetics involved during abscission are considerably slower than what has been observed in retroviral budding, potentially to allow for checkpoints that ensure the fidelity of cytokinesis. For instance, the Aurora B kinase that regulates chromosome contacts with microtubules also phosphorylates CHMP4C (a CHMP4B paralog), which causes CHMP4C to concentrate at the midbody ${ }^{50}$. As a result, abscission is inhibited, possibly signifying that phosphorylated CHMP4C interferes with the function of CHMP4B. Another intriguing possibility is that the timing of scission is regulated by tension: pulling forces between daughter cells were found to prolong their connection, whereas relaxation of this tension coincided with ESCRT-III assembly and subsequent abscission $^{51}$. A role for tension in functions of the ESCRT machinery that drive the ILV budding pathway has also been modeled by using data derived from a variety of studies ${ }^{52}$.

\section{ESCRTs and the biogenesis of extracellular vesicles}

Components of the ESCRT machinery have also been linked to the formation of extracellular vesicles (EVs) that are secreted by many (if not all) cell types. EVs serve as shuttles that mediate intercellular exchange of proteins, RNAs, and lipids, and their functions in humans have been shown to have critical physiological roles in the immune, cardiovascular, and nervous systems ${ }^{53,54}$. Two types of EVs have been defined, and they can be readily distinguished by the way in which they are secreted. EVs known as exosomes originate as ILVs within endosomes and are released from the cell when late endosomes fuse with the plasma membrane rather than a lysosome (Figure 1D); EVs known as ectosomes (or shedding vesicles or microvesicles) bud directly from the plasma membrane (Figure 1E).

A connection between exosome biogenesis and the ILV budding pathway is easy to imagine because they have a common origin, and several proteomic studies had identified ESCRT proteins in purified exosomes (reviewed in 55). However, an ESCRT-independent lipid-driven model for exosome biogenesis had originally been invoked by the observation that ceramide, which resides in the inner leaflet of the exosomal membrane, has a small head group and forms extended hydrogen bond networks that cluster this lipid species into microdomains favorable toward budding into the endosome lumen ${ }^{56}$. The ESCRT machinery was subsequently realized to have a role in exosome biogenesis when it was discovered that syndecan heparan sulfate proteoglycans (one type of cargo packaged into exosomes) interact via a cytoplasmic adaptor protein with ALIX, and exosome budding is blocked upon knocking down expression of ALIX, VPS4, or CHMP4 subunits of the ESCRT-III complex ${ }^{57}$. This finding indicates that exosomal cargoes can nucleate exosome budding through recruitment of at least a subset of the ESCRT machinery, analogous to the way in which retroviral proteins recruit ESCRTs to bud from infected cells.

Evidence was also obtained that the ESCRT machinery functions in ectosome biogenesis. One report showed that knocking down VPS4 expression in C. elegans inhibits ectosome production ${ }^{58}$, whereas another showed that a human arrestin domain-containing protein that binds the TSG101 subunit of ESCRT-I is packaged into ectosomes, 
and the budding of these ectosomes was blocked by knocking down expression of TSG101 or VPS4 ${ }^{59}$. TSG101 and VPS4 were similarly reported to be required for the release of ectosomes loaded with human T-cell receptors into the immunological synapse ${ }^{60}$.

Our understanding of the roles played by ESCRTs in the biogenesis of EVs is still in its infancy, and many details need to be worked out. For instance, do all cell types employ the same set of ESCRTs for exosome or ectosome budding (or both)? In ectosome biogenesis, do ESCRTs function in membrane deformation, as they appear to do in the ILV budding pathway ${ }^{13}$, or do they function predominately in membrane scission? And beyond ESCRTs, what determines whether an endosome fuses with the plasma membrane to release exosomes instead of fusing with a lysosome to deliver ILVs to their destruction?

\section{A new frontier?}

The past year witnessed two discoveries revealing new potential roles for the ESCRT machinery. The repair of small $(<100 \mathrm{~nm})$ lesions in the plasma membrane was found to require ESCRT-III (Figure 1F; 61). In this case, however, it remains unclear whether ESCRT-III has a direct role, as the kinetics of its recruitment to wounded plasma membranes are a few seconds slower than the observed amount of time required for repair to occur ${ }^{62,63}$. One possibility is that remodeling of the plasma membrane occurs in response to wounding and that this process depends directly on ESCRT-III function ${ }^{64}$. More radically, ESCRT-III and VPS4 were found to be required at the inner nuclear membrane for the removal of defective nuclear pore complex (NPC) assembly intermediates (Figure $1 \mathrm{G} ; 65$ ), but how they might function in this process is unknown. One possibility is that nucleoporins extracted from defective NPCs are packaged by ESCRT-III/VPS4 into vesicles, but nucleoporin degradation mediated by this quality-control pathway appears to involve proteasomal degradation, the substrates of which cannot be membrane-bound. Thus, although it is still too early to tell whether the additional duties ascribed to ESCRTs in plasma membrane wound repair and NPC quality control are mediated by any of the functions already known for the ESCRT machinery, these unexpected findings signal a new frontier of understanding how ESCRTs have evolved from their apparently primordial beginning in cell division.

Competing interests

The author declares that he has no competing interests.

Grant information

The author(s) declared that no grants were involved in supporting this work.
1. Raymond CK, Howald-Stevenson I, Vater CA, et al.: Morphological classification of the yeast vacuolar protein sorting mutants: evidence for a prevacuolar compartment in class E vps mutants. Mol Biol Cell. 1992; 3(12): 1389-402. PubMed Abstract | Publisher Full Text | Free Full Text

2. Odorizzi G, Babst M, Emr SD: Fab1p Ptdlns(3)P 5-kinase function essential for protein sorting in the multivesicular body. Cell. 1998; 95(6): 847-58. PubMed Abstract | Publisher Full Text

3. F Odorizzi G, Katzmann DJ, Babst M, et al.: Bro1 is an endosome-associated protein that functions in the MVB pathway in Saccharomyces cerevisiae. J Cell Sci. 2003; 116(Pt 10): 1893-903.

PubMed Abstract | Publisher Full Text | F1000 Recommendation

4. F Katzmann DJ, Babst M, Emr SD: Ubiquitin-dependent sorting into the multivesicular body pathway requires the function of a conserved endosomal protein sorting complex, ESCRT-I. Cell. 2001; 106(2): 145-55. PubMed Abstract | Publisher Full Text | F1000 Recommendation

5. F Babst M, Katzmann DJ, Snyder WB, et al.: Endosome-associated complex, ESCRT-II, recruits transport machinery for protein sorting at the multivesicular body. Dev Cell. 2002; 3(2): 283-9.

PubMed Abstract | Publisher Full Text | F1000 Recommendation

6. $\quad F$ Babst M, Katzmann DJ, Estepa-Sabal EJ, et al.: Escrt-III: an endosomeassociated heterooligomeric protein complex required for mvb sorting. Dev Cell. 2002; 3(2): 271-82.

PubMed Abstract | Publisher Full Text | F1000 Recommendation

7. F Bilodeau PS, Urbanowski JL, Winistorfer SC, et al.: The Vps27p Hse1p complex binds ubiquitin and mediates endosomal protein sorting. Nat Cell Biol. 2002; 4(7): 534-9.

PubMed Abstract | Publisher Full Text | F1000 Recommendation

8. $F$ Leung KF, Dacks JB, Field MC: Evolution of the multivesicular body ESCRT machinery; retention across the eukaryotic lineage. Traffic. 2008; 9(10): 1698-716.

PubMed Abstract | Publisher Full Text | F1000 Recommendation
9. F Obita T, Saksena S, Ghazi-Tabatabai S, et al: Structural basis for selective recognition of ESCRT-III by the AAA ATPase Vps4. Nature. 2007; 449(7163): 735-9.

PubMed Abstract | Publisher Full Text | F1000 Recommendation

10. F Samson RY, Obita T, Freund SM, et al.: A role for the ESCRT system in cell division in archaea. Science. 2008; 322(5908): 1710-3. PubMed Abstract | Publisher Full Text | Free Full Text | F1000 Recommendation

11. Alam SL, Sun J, Payne M, et al.: Ubiquitin interactions of NZF zinc fingers. EMBO J. 2004; 23(7): 1411-21.

PubMed Abstract | Publisher Full Text | Free Full Text

12. Hicke L: Ubiquitin-dependent internalization and down-regulation of plasma membrane proteins. FASEB J. 1997; 11(14): 1215-26. PubMed Abstract

13. F Wollert T, Wunder C, Lippincott-Schwartz J, et al.: Membrane scission by the ESCRT-III complex. Nature. 2009; 458(7235): 172-7. PubMed Abstract | Publisher Full Text | Free Full Text | F1000 Recommendation

14. F Wollert T, Hurley JH: Molecular mechanism of multivesicular body biogenesis by ESCRT complexes. Nature. 2010; 464(7290): 864-9. PubMed Abstract | Publisher Full Text | Free Full Text | F1000 Recommendation

15. $\mathrm{F}$ Lin $\mathrm{Y}$, Kimpler LA, Naismith TV, et al:: Interaction of the mammalian endosomal sorting complex required for transport (ESCRT) III protein hSnf7-1 with itself, membranes, and the AAA ${ }^{+}$ATPase SKD1. J Biol Chem. 2005; 280(13): 12799-809.

12799-809.
PubMed Abstract | Publisher Full Text | F1000 Recommendation

16. $\mathrm{F}$ Muziol T, Pineda-Molina E, Ravelli RB, et al:: Structural basis for budding by the ESCRT-III factor CHMP3. Dev Cell. 2006; 10(6): 821-30. PubMed Abstract | Publisher Full Text | F1000 Recommendation

17. F Lata S, Schoehn G, Jain A, et al:: Helical structures of ESCRT-III are disassembled by VPS4. Science. 2008; 321(5894): 1354-7. PubMed Abstract | Publisher Full Text | Free Full Text | F1000 Recommendation 
18. Bajorek M, Schubert HI, McCullough J, et al: Structural basis for ESCRT-III protein autoinhibition. Nat Struct Mol Biol. 2009; 16(7): 754-62. PubMed Abstract | Publisher Full Text | Free Full Text

19. Martinelli N, Hartlieb B, Usami Y, et al:: CC2D1A is a regulator of ESCRT-III CHMP4B. J Mol Biol. 2012; 419(1-2): 75-88. PubMed Abstract | Publisher Full Text | Free Full Text

20. F Hanson PI, Roth R, Lin Y, et al:: Plasma membrane deformation by circular arrays of ESCRT-III protein filaments. J Cell Biol. 2008; 180(2): 389-402. PubMed Abstract | Publisher Full Text | Free Full Text | F1000 Recommendation

21. F Guizetti J, Schermelleh L, Mäntler J, et al:: Cortical constriction during abscission involves helices of ESCRT-III-dependent filaments. Science. 2011; 331(6024): 1616-20.

PubMed Abstract | Publisher Full Text | F1000 Recommendation

22. F Teis D, Saksena S, Emr SD: Ordered assembly of the ESCRT-III complex on endosomes is required to sequester cargo during MVB formation. Dev Cell. 2008; 15(4): 578-89.

PubMed Abstract | Publisher Full Text | F1000 Recommendation

23. Hanson PI, Cashikar A: Multivesicular body morphogenesis. Annu Rev Cell Dev Biol. 2012; 28: 337-62.

PubMed Abstract | Publisher Full Tex

24. Fabrikant G, Lata S, Riches JD, et al.: Computational model of membrane fission catalyzed by ESCRT-III. PLoS Comput Biol. 2009; 5(11): e1000575. PubMed Abstract | Publisher Full Text | Free Full Text

25. Wemmer M, Azmi I, West M, et al.: Bro1 binding to Snf7 regulates ESCRT-II membrane scission activity in yeast. J Cell Biol. 2011; 192(2): 295-306. PubMed Abstract | Publisher Full Text | Free Full Text

26. F Adell MA, Vogel GF, Pakdel M, et al.: Coordinated binding of Vps4 to ESCRT-III drives membrane neck constriction during MVB vesicle formation. J Cell Biol. 2014; 205(1): 33-49.

PubMed Abstract | Publisher Full Text | Free Full Text | F1000 Recommendation

27. F Stuchell-Brereton MD, Skalicky JJ, Kieffer C, et al.: ESCRT-III recognition by VPS4 ATPases. Nature. 2007; 449(7163): 740-4.

PubMed Abstract | Publisher Full Text | F1000 Recommendation

28. Kieffer C, Skalicky JJ, Morita E, et al:: Two distinct modes of ESCRT-III recognition are required for VPS4 functions in lysosomal protein targeting and HIV-1 budding. Dev Cell. 2008; 15(1): 62-73.

PubMed Abstract | Publisher Full Text | Free Full Text

29. F Saksena S, Wahlman J, Teis D, et al: Functional reconstitution of ESCRT-II assembly and disassembly. Cell. 2009; 136(1): 97-109. PubMed Abstract | Publisher Full Text | Free Full Text | F1000 Recommendation

30. F Cashikar AG, Shim S, Roth R, et al.: Structure of cellular ESCRT-III spirals and their relationship to HIV budding Elife. 2014: 3: e02184. PubMed Abstract | Publisher Full Text | Free Full Text | F1000 Recommendation

31. F Shen QT, Schuh AL, Zheng $Y$, et al.: Structural analysis and modeling reveals new mechanisms governing ESCRT-III spiral filament assembly. $\mathrm{J}$ Cell Biol. 2014; 206(6): 763-77.

PubMed Abstract | Publisher Full Text | Free Full Text | F1000 Recommendation

32. F Garrus JE, von Schwedler UK, Pornillos OW, et al:: Tsg101 and the vacuolar protein sorting pathway are essential for HIV-1 budding. Cell. 2001; 107(1): 55-65. PubMed Abstract | Publisher Full Text | F1000 Recommendation

33. McCullough J, Colf LA, Sundquist WI: Membrane fission reactions of the mammalian ESCRT pathway. Annu Rev Biochem. 2013; 82: 663-92. PubMed Abstract | Publisher Full Text | Free Full Text

34. F Carlson LA, Hurley JH: In vitro reconstitution of the ordered assembly of the endosomal sorting complex required for transport at membrane-bound HIV-1 Gag clusters. Proc Natl Acad Sci U S A. 2012; 109(42): 16928-33. PubMed Abstract | Publisher Full Text | Free Full Text | F1000 Recommendation

35. F Strack B, Calistri A, Craig S, et al:: AIP1/ALIX is a binding partner for HIV-1 p6 and EIAV p9 functioning in virus budding. Cell. 2003; 114(6): 689-99. PubMed Abstract | Publisher Full Text | F1000 Recommendation

36. F Zamborlini A, Usami Y, Radoshitzky SR, et al:: Release of autoinhibition converts ESCRT-III components into potent inhibitors of HIV-1 budding. ProC Natl Acad SciU S A. 2006; 103(50): 19140-5.

PubMed Abstract | Publisher Full Text | Free Full Text | F1000 Recommendation

37. F Shim S, Kimpler LA, Hanson PI: Structure/function analysis of four core ESCRT-III proteins reveals common regulatory role for extreme C-terminal domain. Traffic. $2007 ; \mathbf{8}(8)$ : 1068-79.

PubMed Abstract | Publisher Full Text | F1000 Recommendation

38. F Van Engelenburg SB, Shtengel G, Sengupta $P$, et al:: Distribution of ESCRT machinery at HIV assembly sites reveals virus scaffolding of ESCRT subunits. Science. 2014; 343(6171): 653-6.

PubMed Abstract | Publisher Full Text | F1000 Recommendation
39. $\mathrm{F}$ Baumgärtel V, Ivanchenko S, Dupont $\mathrm{A}$, et al:: Live-cell visualization of dynamics of HIV budding site interactions with an ESCRT component. Nat Cell Biol. 2011; 13(4): 469-74. PubMed Abstract | Publisher Full Text | F1000 Recommendation

40. F Jouvenet $\mathrm{N}$, Zhadina M, Bieniasz PD, et al.: Dynamics of ESCRT protein recruitment during retroviral assembly. Nat Cell Biol. 2011; 13(4): 394-401. PubMed Abstract | Publisher Full Text | Free Full Text | F1000 Recommendation

41. Mierzwa B, Gerlich DW: Cytokinetic abscission: molecular mechanisms and temporal control. Dev Cell. 2014; 31(5): 525-38. PubMed Abstract | Publisher Full Text

42. F Carlton JG, Martin-Serrano J: Parallels between cytokinesis and retroviral budding: a role for the ESCRT machinery. Science. 2007; 316(5833): 1908-12. PubMed Abstract | Publisher Full Text | F1000 Recommendation

43. F Morita E, Sandrin V, Chung HY, et al.: Human ESCRT and ALIX proteins interact with proteins of the midbody and function in cytokinesis. EMBO J. 2007; 26(19): 4215-27.

PubMed Abstract | Publisher Full Text | Free Full Text | F1000 Recommendation

44. F Lee HH, Elia N, Ghirlando R, et al:: Midbody targeting of the ESCRT machinery by a noncanonical coiled coil in CEP55. Science. 2008; 322(5901): 576-80. PubMed Abstract | Publisher Full Text | Free Full Text | F1000 Recommendation

45. Martin-Serrano J, Yarovoy A, Perez-Caballero D, et al.: Divergent retroviral latebudding domains recruit vacuolar protein sorting factors by using alternative adaptor proteins. Proc Natl Acad Sci U S A. 2003; 100(21): 12414-9. PubMed Abstract | Publisher Full Text | Free Full Text

46. F von Schwedler UK, Stuchell M, Müller B, et al.: The protein network of HIV budding. Cell. 2003; 114(6): 701-13. PubMed Abstract | Publisher Full Text | F1000 Recommendation

47. Henne WM, Buchkovich NJ, Zhao Y, et al:: The endosomal sorting complex ESCRT-II mediates the assembly and architecture of ESCRT-III helices. Cell. 2012; 151(2): 356-71.

PubMed Abstract | Publisher Full Text

48. F Lindås $\mathrm{AC}$, Karlsson $\mathrm{EA}$, Lindgren $\mathrm{MT}$, et al: $\mathbf{A}$ unique cell division machinery in the Archaea. Proc Natl Acad Sci U S A. 2008; 105(48): 18942-6. PubMed Abstract | Publisher Full Text | Free Full Text | F1000 Recommendation

49. F Elia N, Sougrat R, Spurlin TA, et al.: Dynamics of endosomal sorting complex required for transport (ESCRT) machinery during cytokinesis and its role in abscission. Proc Natl Acad Sci U S A. 2011; 108(12): 4846-51. PubMed Abstract | Publisher Full Text | Free Full Text | F1000 Recommendation

50. F Carlton JG, Caballe A, Agromayor M, et al.: ESCRT-III governs the Aurora B-mediated abscission checkpoint through CHMP4C. Science. 2012; 336(6078): $220-5$.

PubMed Abstract | Publisher Full Text | Free Full Text | F1000 Recommendation

51. $\quad F$ Lafaurie-Janvore J, Maiuri $P$, Wang I, et al.: ESCRT-III assembly and cytokinetic abscission are induced by tension release in the intercellula bridge. Science. 2013; 339(6127): 1625-9.

PubMed Abstract | Publisher Full Text | F1000 Recommendation

52. F Różycki B, Boura E, Hurley JH, et al.: Membrane-elasticity model of Coatless vesicle budding induced by ESCRT complexes. PLOS Comput Biol. 2012; 8(10): e1002736.

PubMed Abstract | Publisher Full Text | Free Full Text | F1000 Recommendation

53. Raposo G, Stoorvogel W: Extracellular vesicles: exosomes, microvesicles, and friends. J Cell Biol. 2013; 200(4): 373-83. PubMed Abstract | Publisher Full Text | Free Full Text

54. Cocucci E, Meldolesi J: Ectosomes and exosomes: shedding the confusion between extracellular vesicles. Trends Cell Biol. 2015; 25(6): 364-72. PubMed Abstract | Publisher Full Text

55. Choi DS, Kim DK, Kim YK, et al.: Proteomics of extracellular vesicles: Exosomes and ectosomes. Mass Spectrom Rev. 2015; 34(4): 474-90. PubMed Abstract | Publisher Full Text

56. $\mathrm{F}$ Trajkovic $\mathrm{K}$, Hsu C, Chiantia S, et al.: Ceramide triggers budding of exosome vesicles into multivesicular endosomes. Science. 2008; 319(5867): 1244-7. PubMed Abstract | Publisher Full Text | F1000 Recommendation

57. F Baietti MF, Zhang Z, Mortier E, et al.: Syndecan-syntenin-ALIX regulates the biogenesis of exosomes. Nat Cell Biol. 2012; 14(7): 677-85. PubMed Abstract | Publisher Full Text | F1000 Recommendation

58. F Wehman AM, Poggioli C, Schweinsberg P, et al:: The P4-ATPase TAT-5 inhibits the budding of extracellular vesicles in C. elegans embryos. Curr Biol. 2011; 21(23): 1951-9.

PubMed Abstract | Publisher Full Text | Free Full Text | F1000 Recommendation

59. F Nabhan JF, Hu R, Oh RS, et al:: Formation and release of arrestin domaincontaining protein 1-mediated microvesicles (ARMMs) at plasma membrane 
by recruitment of TSG101 protein. Proc Natl Acad Sci U S A. 2012; 109(11): 4146-51.

PubMed Abstract | Publisher Full Text | Free Full Text | F1000 Recommendation

60. F Choudhuri K, Llodrá J, Roth EW, et al:: Polarized release of T-cell-receptorenriched microvesicles at the immunological synapse. Nature. 2014; 507(7490): $118-23$.

PubMed Abstract | Publisher Full Text | Free Full Text | F1000 Recommendation

61. F Jimenez AJ, Maiuri P, Lafaurie-Janvore J, et al.: ESCRT machinery is

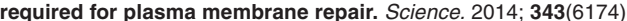
1247136.

PubMed Abstract | Publisher Full Text | F1000 Recommendation

62. F Lennon NJ, Kho A, Bacskai BJ, et al.: Dysferlin interacts with annexins A1 and $A 2$ and mediates sarcolemmal wound-healing. $J$ Biol Chem. 2003; 278(50): 50466-73.

PubMed Abstract | Publisher Full Text | F1000 Recommendation

63. F Corrotte M, Almeida PE, Tam C, et al.: Caveolae internalization repairs wounded cells and muscle fibers. Elife. 2013; 2: e00926.

PubMed Abstract | Publisher Full Text | Free Full Text | F1000 Recommendation

64. Andrews NW, Almeida PE, Corrotte M: Damage control: cellular mechanisms of plasma membrane repair. Trends Cell Biol. 2014; 24(12): 734-42. PubMed Abstract | Publisher Full Text | Free Full Text

65. $\mathrm{F}$ Webster BM, Colombi $\mathrm{P}$, Jäger J, et al.: Surveillance of nuclear pore complex assembly by ESCRT-III/Vps4. Cell. 2014; 159(2): 388-401.

PubMed Abstract | Publisher Full Text | Free Full Text | F1000 Recommendation 


\section{Open Peer Review}

\section{Current Peer Review Status:}

\section{Version 1}

Reviewer Report 07 August 2015

https://doi.org/10.5256/f1000research.6776.r9924

(C) 2015 Hanson P. This is an open access peer review report distributed under the terms of the Creative Commons Attribution License, which permits unrestricted use, distribution, and reproduction in any medium, provided the original work is properly cited.

\section{Phyllis Hanson}

Department of Cell Biology \& Physiology, Washington University School of Medicine, St. Louis, MO, USA

Competing Interests: No competing interests were disclosed.

I confirm that I have read this submission and believe that I have an appropriate level of expertise to confirm that it is of an acceptable scientific standard.

Reviewer Report 07 August 2015

https://doi.org/10.5256/f1000research.6776.r9921

(C) 2015 Audhya J. This is an open access peer review report distributed under the terms of the Creative Commons Attribution License, which permits unrestricted use, distribution, and reproduction in any medium, provided the original work is properly cited.

\section{Jon Audhya}

Department of Biomolecular Chemistry, University of Wisconsin-Madison, Madison, WI, 53706, USA

Competing Interests: No competing interests were disclosed.

I confirm that I have read this submission and believe that I have an appropriate level of expertise to confirm that it is of an acceptable scientific standard.

Reviewer Report 07 August 2015 


\section{https://doi.org/10.5256/f1000research.6776.r9925}

(c) 2015 Weissenhorn W. This is an open access peer review report distributed under the terms of the Creative Commons Attribution License, which permits unrestricted use, distribution, and reproduction in any medium, provided the original work is properly cited.

\section{Winfried Weissenhorn}

Unit of Virus Host Cell Interactions, University Joseph Fourier, Grenoble, France

Competing Interests: No competing interests were disclosed.

I confirm that I have read this submission and believe that I have an appropriate level of expertise to confirm that it is of an acceptable scientific standard.

Reviewer Report 07 August 2015

https://doi.org/10.5256/f1000research.6776.r9923

(C) 2015 Teis D. This is an open access peer review report distributed under the terms of the Creative Commons Attribution License, which permits unrestricted use, distribution, and reproduction in any medium, provided the original work is properly cited.

\section{David Teis}

Innsbruck Medical University, Innsbruck, Austria

Competing Interests: No competing interests were disclosed.

I confirm that I have read this submission and believe that I have an appropriate level of expertise to confirm that it is of an acceptable scientific standard. 
The benefits of publishing with F1000Research:

- Your article is published within days, with no editorial bias

- You can publish traditional articles, null/negative results, case reports, data notes and more

- The peer review process is transparent and collaborative

- Your article is indexed in PubMed after passing peer review

- Dedicated customer support at every stage

For pre-submission enquiries, contact research@f1000.com 